\title{
Research on Tort Liability Law and Contract Law Boundary Based on the Expansion of Tort Liability Law
}

\author{
Wenhui Wang \\ Department of Services for Foreign Ministry, Chaoyang District, Beijing, China, 100020
}

Keywords: Tort liability law, expansion, tort liability law, contract law, boundary, research

Abstract: With the development of society, the scope of application of tort liability law has been continuously expanded, and the object of adjustment of tort liability law and contract law is constantly changing. This paper analyzes the significance of the tort liability law and the contract law boundary, studies the boundary between the tort liability law and the contract law, and explores how to coordinate the tort liability law and the contract law.

\section{Introduction}

In recent years, the scope of application of tort liability law has been expanding, and it has gradually penetrated into the field of traditional contract law. The boundary between contract law and tort liability law has been affected to some extent. With the expansion of the Tort Liability Law, it will have a certain impact on our civil law mechanism, and even seriously affect the justice of the judiciary. Since the contract law and the tort liability law are different laws and their scope of application is different, there is also a difference in law enforcement concepts. We need to study the boundaries of these two laws in depth and use these two laws to solve various social problems.

\section{The Significance of the Tort Liability Law and the Contract Law Boundary}

With the development of society, the tort liability law has expanded, which is of great significance to ensure the legitimate rights and interests of the people. In addition, the scope of application of traditional contract law is not wide enough, so people often have some restrictions when using contract law to deal with problems, so the scope of application of tort liability law will gradually expand. There is a partial scope of integration between tort liability law and contract law, so these two laws can be used to deal with some social issues. Compared with the contract law, the Tort Liability Law is more secure. People can obtain compensation and compensation through the Tort Liability Law. For example, the Tort Liability Law is combined with liability insurance and social assistance, which can effectively solve the problems encountered by the people. All kinds of problems protect the legitimate rights and interests of the people.

Although the scope of application of the Tort Liability Law is constantly expanding, and people attach more importance to the Tort Liability Law, the expansion of the Tort Liability Law will also have certain adverse effects. For example, the expansion of the Tort Liability Law will affect the harmony and balance of the mechanism of internal civil law. Article 122 of the Contract Law stipulates that in the case of co-opetition, the victim may choose the form of liability and choose the 
liability for breach of contract or tort liability according to the specific circumstances, and may limit the choice of the victim. However, with the expansion of the Tort Liability Act, the victim's choice may be compromised. In addition, with the expansion of the Tort Liability Law, it will also affect judicial practice. For example, when a judge hears a case, the discretion will gradually expand. According to the relevant provisions of the traditional contract law, the judge only needs to judge whether the performance of one of the parties is qualified. With the expansion of the Tort Liability Law, judges can use the Tort Liability Law when trying cases, which will increase the workload of the judges, which may lead to other disputes and affect the outcome of judicial decisions.

With the continuous expansion of the scope of application of the Tort Liability Law, while bringing convenience to people, it also increases the contradiction between the Tort Liability Law and the traditional contract law, which in turn causes certain negative impacts. Therefore, in order to build a fair and just legal society, the scientific community needs to be divided into tort liability law and contract law.

\section{The Boundary of Tort Liability Law and Contract Law}

\subsection{Study on the Value of Contract Law and Tort Liability Law Boundary}

To divide the contract law and tort liability law for the scientific community, it is necessary to fully understand the basic values of the two laws. The basic value of contract law is private law autonomy, and the principle of freedom of contract fully reflects the value of private law autonomy in contract law. The contract law belongs to the transaction law and the property law. Whether it is to encourage transactions to promote economic growth or to maintain the trading system, it is necessary to follow the concept of private law autonomy. To put it simply, private law autonomy is the right connection of the parties with equal rights to negotiate on their own. The parties have the right to decide on the contract with whom, whether to sign the contract and the content of the contract. If the content of the contract conforms to the social interests, moral concepts, and relevant laws and regulations, it can be determined that the contract is a valid contract, and the autonomy of private law determines the function, composition, and responsibility of the contract law. The Tort Liability Law is different from the Contract Law. It does not belong to the Transaction Law and the Property Law. Its function is not to encourage transactions to promote economic growth, but it also allows the principle of private law autonomy to be embodied. Compared with the contract law, the tort liability law has a small space for private law autonomy, and it is mainly applied to humanistic care. The Tort Liability Law is a forcible law and a remedy law. Its main function is to protect the legitimate rights and interests of the victims, especially to protect the personal rights of the people. If the legitimate rights and interests of the victim are infringed, the Tort Liability Law can assume corresponding responsibilities through state intervention to protect the rights and interests of the victim. This is also an important content different from civil law. Therefore, the contract law and the tort liability law have the following differences:

First of all, the contractual relationship is different. The contract law relationship is mainly to distinguish between infringement and breach of contract standards. To put it simply, the contractual relationship is the relationship that is formed before the contract is signed, and it also applies to the Tort Liability Act.

Second, the sources of obligations are different. According to the relevant provisions of the Contract Law, the parties are free to agree on their respective rights and obligations, and both parties also recognize their respective rights and obligations. Therefore, it is possible to distinguish between tort liability and liability for breach of contract by analyzing whether the type of obligation is an agreed obligation or a statutory obligation. Often, legal obligations can also be called general obligations.

Finally, the responsibility is different. According to the requirements of the principle of autonomy 
of private law, the parties can pre-arrange their respective responsibilities in accordance with social responsibilities and legal requirements, thereby reducing the difficulty of calculating responsibilities and losses. In the contractual liability, the parties can scientifically determine the default loss by means of prior agreement, so as to calculate and compensate for the loss after the breach of contract.

\subsection{Study on the Scope of Protection of Contract Law and Tort Liability Law}

The Tort Liability Law mainly determines the object of protection based on the private rights other than the relief contract. The contract law is based on the principle of private law autonomy to achieve the will of the parties, the main purpose of which is to protect the legitimate interests of the parties. Therefore, the contract law and the tort liability law have the following differences in terms of protection:

First, the scope of the benefit compensation is determined according to the contract. We can distinguish between the inherent interests and the performance benefits according to the relevant provisions of the contract law to protect claims. Therefore, it is necessary to clearly clarify the scope of benefits and the scope of compensation according to the purpose of the contract. However, when analyzing the inherent benefits, it is not necessary to analyze the contractual purpose.

Second, the standard of interest compensation is different. If the contract law is chosen to protect its own rights, it means that the parties need to meet the actual interests of the contract and ensure that the victim has fulfilled the obligations stipulated in the contract. If the tort liability law is used to protect one's rights and interests, it is necessary to study the full compensation aspect, the purpose of which is to restore the property and personal situation of the victim before the violation.

Finally, can the victim request actual performance. In the liability for breach of contract, the main purpose of signing the contract between the two parties is to obtain the benefits stipulated in the contract. Therefore, if the other party has a breach of contract, the non-defaulting party may apply to the court to require the defaulting party to perform its duties according to the contract, thereby satisfying the contract. The goal. However, in the tort liability, the importance is to protect the inherent interests of both parties to the contract. Therefore, in the event that the legitimate rights and interests of the victim are impaired, compensation cannot be made in accordance with the contract.

\subsection{The Division of Contract Law and Tort Liability Law in Legal Liability}

If the object and content of the contract law and the tort liability law are not clear, it will not only affect the scope of application of the law but also affect the entire legal mechanism. The infringement liability and the liability for breach of contract are different, so the results are different. The differences between the contract law and the tort liability law are mainly reflected in the following points:

First of all, about the fault elements. The principle of contractual liability applies to strict liability. According to the development trend of the contract, the contract is gradually developing towards strict liability. To put it simply, a non-defaulting party can prove that the defaulting party has breached the contract and assumes its own responsibility. It does not need to prove whether the defaulting party is subjectively at fault.

Second, clear the causal relationship. The causal relationship in law refers to the relationship between the damage result and the cause, which is also an important link in judging their respective responsibilities. From the perspective of tort liability law, causality refers to the important reasons that constitute infringement. Whether it is strict liability or fault liability, causality plays an important role in the identification of legal liability. However, in contract law, causality refers to the factors that lead to the damage, and its importance is lower than the tort liability.

Again, proof of damage. The important component of tort liability is damage. However, if both 
parties to the contract have specified a liquidated damages or damages method, the victim does not need to provide evidence. In addition, it should be noted that the tort liability includes personal injury and compensation for mental damage, but the contractual liability does not include both types of compensation.

Finally, proof of excuses and so on. There are fewer statutory exemptions in contractual liability, that is, force majeure. Therefore, it is necessary to clarify whether the liability of the perpetrator can be waived based on the scope of the force majeure. In addition, the parties may also clarify the exemption clause in the contract. However, in the Tort Liability Law, the parties are not free to agree on excuses. Therefore, the parties are required to stipulate exemption clauses in accordance with the law.

\subsection{Study on the Legal Effect of Contract Law and Tort Liability Law Boundary}

From the perspective of legal effects, the contract law protects the issue of contractual claims, and its purpose is to help victims of property damage. In addition, the transaction law will affect the damage principle of the contract law. In short, the damage compensation needs to meet the agreed loss of both parties at the time of signing the contract. According to this principle, contractual liability does not include compensation for mental damage. The Tort Liability Law protects losses other than contractual claims and primarily protects the parties' inherent interests. Thus, the Tort Liability Act contains property damage, mental compensation, and personal injury. It can be seen that the scope of protection of contract law and tort liability is different. The analysis of the legal effects of the contract law and the tort liability law can not only bear the social responsibility of the incident, but also link the civil law responsibility mechanism. From the perspective of legal effects, the division of tort liability law and contract law for science should pay attention to personal injury compensation and mental damage compensation.

\section{How to Coordinate the Tort Liability Law and the Contract Law}

Through the above analysis, the tort liability law and the contract law are different in terms of scope of protection, legal liability, and legal effects. How to coordinate the tort liability law and the contract law to protect the legitimate rights and interests of the parties is a problem we need to ponder.

\subsection{Give Full Play to the Protection of the Tort Liability Law and the Contract Law on the Interests of Economic Subjects}

The main function of the contract law is to regulate the market economic order. According to the principle of private law autonomy, the parties sign the contract in the case of mutual agreement. When mediating disputes, the legality and standardization of market transactions can be guaranteed by reducing invalid contracts. The parties may, without complying with relevant laws and regulations and social order, sign contracts freely through negotiation to promote transactions and promote the stable development of China's social economy. The Tort Liability Law is mainly to protect the absolute rights of the parties. The purpose is to remedy the damage caused to the victims during the infringement. For example, tourists and travel companies sign travel contracts. During the travel process, the travel companies need to ensure the personal and property safety of the tourists. If the personal or property safety of the visitor is violated in the tourist service place, the visitor may file an infringement lawsuit against the service operator in the court, and in the course of the lawsuit, the infringement lawsuit and the breach of contract lawsuit may be filed against the travel company. Subject to the contract law, visitors can only file infringement lawsuits with third parties to the contract. It can be seen that compared with the contract law, the Tort Liability Law pays more 
attention to protecting the personal rights and interests of the people.

\subsection{Clarify the Responsibility between the Tort Liability Law and the Contract Law}

If an infringement occurs during the performance of the contract, the party is free to choose whether to file a breach of contract or an infringement suit. First of all, the two sides can negotiate and mediate; secondly, they can clarify the responsible party according to the constitutive elements of the responsibility, thereby protecting the legitimate rights and interests of the parties and narrowing the scope of the tort liability law. In order to avoid the court's judgment according to the tort liability, the parties are given the opportunity to provide evidence exemption, thereby affecting the legitimate rights and interests of the parties, and the supplementary role of the tort liability law in protecting the legitimate rights and interests of the parties must be guaranteed. In addition, the contract law attaches importance to the protection of the property rights of the parties, so the contractual liability caused by the contract breach can be evaluated by money. The Tort Liability Law attaches importance to the protection of the property and personal safety of the parties. Therefore, it includes personal compensation and moral compensation. By clearly distinguishing the respective responsibilities of the Tort Liability Law and the Contract Law, the parties can effectively enhance the choice of the parties so that the legitimate rights and interests of the parties can be reasonably and legally safeguarded their legitimate rights and interests.

\subsection{Guarantee the Interests Protected by the Tort Liability Law and the Contract Law}

The contract law protects the legitimate interests of the parties after the parties have agreed on the expected benefits and the performance of the contract. The Tort Liability Law mainly protects the personal and property interests of the parties. If the person or property of the party is infringed, it is necessary to protect the legitimate rights and interests of the party by filing an infringement lawsuit. The liability involved in the contract law is similar to the contractual claims. If one party fails to perform or fails to perform its obligations under the contract, the other party has the right to require the defaulting party to perform its own duties, thereby achieving the contract performance. The object of adjustment of the contract is the property rights and interests of the parties. Therefore, if the property rights of the parties are damaged, it is necessary to claim compensation for breach of contract, and cannot claim compensation for mental damage. Compared with the contract law, the tort liability law protects the parties more comprehensively. Therefore, the parties can file a tort lawsuit for spiritual compensation, thereby protecting their personal and property rights.

Strict liability contracts pay more attention to the breach of contract liability of both parties, and do not pay attention to whether the parties are at fault. Under normal circumstances, if there is no force majeure, the parties are not excused, that is, the parties must bear the responsibility for breach of contract caused by themselves. The tort liability law is different, and it mainly decides the responsibility mode according to the actual situation. The contract law and the tort liability law have different definitions of causality. The contract law needs to clarify the scope of compensation and the content of compensation according to the agreement of both parties and the performance of the parties, and the non-defaulting party does not need to provide evidence. The tort liability law shall clarify the liability and compensation of the parties based on the parties' infringement or damage results.

\section{Conclusion}

In summary, with the development of society, the scope of application of the Tort Liability Law is inevitable. As a legal basis for the development of market economy, contract law is of great 
significance to the development of China's society. The organic integration of the Tort Liability Law with the Contract Law is of great significance to the use and development of the contract law. In order to ensure the coordinated development of the Tort Liability Law and the Contract Law, the scientific community should be divided into the Contract Law and the Tort Liability Law, so as to avoid contradictions between laws and affect the legitimate rights and interests of the parties.

\section{References}

[1] Qiang Gao. Research on the Relationship between the Right of Claim and the Way of Liability for Infringement [D]. Jilin University, 2016.

[2] Zhijun Fan. Reflection and Reconstruction of the Relationship between Contract Law and Tort Liability Law [D]. Dalian Maritime University, 2016.

[3] Ying Han. On the Competition of Tort Liability and Breach of Contract Liability in Medical Damage [D]. Yunnan University of Finance and Economics, 2017.

[4] Jing Qin. Research on Liability for Fraud Infringement Damage [D]. Nanjing University, 2017.

[5] Fan Yang. Research on Pure Economic Loss Compensation [D]. Lanzhou University, 2017.

[6] Yunlai Wu. Research on Contract Path of Medical Damage Relief_C Comparing with Infringement Path[J]. Northern Methodology, 2017,11(05):5-16.

Wenhui Wang, FEMALE, SHANDONG, 1992.09.18, Bachelor of Economics/ Bachelor of Laws, nil, School of law/School of finance, The Shandong University of Finance and Economics 